УДК 633.11:631:82

DOI https://doi.org/10.32848/agrar.innov.2021.10.12

\title{
ЕФЕКТИВНІСТЬ ПРИКОРЕНЕВОГО ПІДЖИВЛЕННЯ ПОСІВІВ ПШЕНИЦІ ОЗИМОЇ В ПІВНІЧНОМУ СТЕПУ УКРАЇНИ
}

\author{
МОСТІПАН М.О. - кандидат біологічних наук, професор \\ https://orcid.org/0000-0001-5317-6315 \\ Центральноукраїнський національний технічний університет \\ УМРИХІН Н.Л. - кандидат сільськогосподарських наук \\ https://orcid.org/0000-0002-4220-8606 \\ Інститут сільського господарства Степу Національної академії аграрних наук України
}

Постановка проблеми. Основними чинниками, що забезпечили зростання врожайності польових культур у сільськогосподарському виробництві України, є використання нових сортів та гібридів, застосування більш ефрективних систем обмеження шкодочинних об'єктів у посівах та використання сучасної, продуктивнішої сільськогосподарської техніки, інших специфрічних агротехнічних прийомів. Поряд із цим у багатьох сільськогосподарських підприємствах врожайність польових культур поки що залишається досить низькою та спостерігаються значні її коливання під впливом факторів навколишнього середовища.

Численними дослідженнями доведено, що найбільш ефективним шляхом подолання негативної дії факторів навколишнього середовища $є$ впровадження у виробництво сортів із більш високими адаптивними властивостями рослин та новітніх технологій їх вирощування [1, 2]. Останні повинні включати в себе такі агротехнічні прийоми, які би підвищували адаптивні властивості рослин до несприятливих фракторів. Серед усіх агротехнічних прийомів, що дозволяють розкрити потенційні можливості рослин, найбільш важливе значення мають умови мінерального живлення рослин. Лише рослини, які не відчувають дефіциту в тих чи інших елементах живлення, здатні ефективно протистояти негативній дії фракторів навколишнього середовища та реалізувати свої генетичні можливості щодо насіннєвої продуктивності.

Використання мінеральних добрив $є$ одним із найвпливовіших агротехнічних прийомів на рівень продуктивності посівів пшениці озимої та якість отриманого врожаю [3, 4]. Особливо велика роль відводиться азотним добривам. При цьому добре відомо, що їх дія визначається численною низкою фракторів агротехнічного та природного походження. Тому питання визначення ефективності застосування мінеральних добрив під час вирощування пшениці озимої завжди були актуальними, особливо в останні роки, на фоні істотних кліматичних та структурно-економічних змін в агропромисловому виробництві.

Аналіз останніх досліджень і публікацій. Рослини пшениці озимої $є$ вимогливими до родючості ґрунтів. Про це переконливо свідчать не лише показники виносу елементів живлення, необхідних для формування одиниці врожаю, а й рівень урожайності посівів у сільськогосподарському виробництві без використання добрив. Для формування 1 т зерна та відповідної кількості соломи рослини засвоюють із ґрунту 25-35 кг азоту,
11-13 кг фоссфору, 20-27 кг калію та 3 кг сірки. Потреба рослин в мікроелементах $€$ меншою і становить 5 г бору, 82 г марганцю, 270 г заліза та 60 г цинку[5]. Між рівнем врожайності та виносом елементів живлення із ґрунту відзначається прямолінійний взаємозв'язок. Із підвищенням врожайності обсяги споживання елементів живлення рослинами пшениці зростають [6]. До того ж максимальна реалізація генетичних можливостей того чи іншого сорту можлива за умови оптимального співвідношення між азотом, фосфором та калієм, яке, на думку В.В. Лихочвора [5], становить 1,5 : $1: 1$.

Сучасна система удобрення посівів пшениці озимої включає в себе використання добрив під основний обробіток ґрунту одночасно із сівбою, прикореневі та позакореневі підживлення впродовж вегетації рослин $[7,8]$. Вона ґрунтується на фундаментальних наукових дослідженнях щодо споживання рослинами пшениці озимої елементів живлення із ґрунту. Відомо, що азот вони засвоюють майже впродовж усього періоду вегетації. Але фрізіологічні потреби рослин у цьому елементі $€$ різними. Доведено, що впродовж осінньої вегетації і до часу відновлення її весною рослини пшениці озимої споживають не більше 14\% від загальних його потреб [9]. Тому надмірне азотне живлення рослин восени може мати негативні наслідки для формування врожаю, особливо у роки з тривалим періодом осінньої вегетації. Крім цього, у роки з достатнім чи надмірним зволоженням можливі непродуктивні втрати азоту шляхом вимивання рухомих його фрорм у глибші шари ґрунту [10]. До того ж в умовах північного Степу України найбільш високу врожайність забезпечують посіви, припинення осінньої вегетації яких відбувається у третій декаді листопада [11].

Із настанням фази трубкування потреби рослин пшениці в азотному живленні різко зростають і тривають до фази колосіння. Протягом цього періоду посіви пшениці озимої синтезують найбільшу кількість сухих речовин [12]. Тому завчасно необхідно створити максимально оптимальні умови азотного живлення рослин. Для цього проводять прикореневе підживлення посівів. Воно впливає не лише на щільність посівів пшениці озимої, а й індивідуальну продуктивність рослин [6]. Норма прикореневого підживлення повинна враховувати не лише запаси доступного азоту в ґрунті, а й стан та потенційні можливості посівів та час відновлення весняної вегетації $[13,14]$. Час відновлення весняної вегетації рослин є настільки впливовим, що за своєю дією може перевищувати ефект інших агротехнічних прийомів, що 
використовуються весною. До того ж цей чинник може повністю нівелювати навіть вплив строків сівби $[15,16]$.

Прикореневе підживлення посівів пшениці озимої наприкінці фрази кущіння рослин не лише забезпечує підвищення їх продуктивності, а й визначає можливості отримання високоякісного зерна. Позакореневі підживлення посівів пшениці озимої азотом в подальшому будуть ефективними лише за певного вмісту азоту у надземній масі рослин. За низького вмісту азоту у вегетативних органах рослин менше $1,0 \%$ на абсолютно суху речовину проведення позакореневого підживлення посівів не забезпечить отримання високоякісного зерна. Вони будуть ефективними лише за вмісту азоту у межах від 1,0 до 3,0\% [17]. Тому проведення прикореневих підживлень посівів необхідно розглядати з погляду не лише підвищення їх урожайності, а й створення передумов формування високоякісного зерна.

Мета. Головна мета досліджень полягала у визначенні ефективності проведення прикореневого підживлення посівів пшениці озимої після сої на зерно за пізніх строків сівби.

Матеріали та методика досліджень. Польові дослідження проводили в Інституті сільського господарства Степу НААН впродовж 2017-2020 років. Пшеницю озиму сорту Антонівка висівали після сої у різні строки: 15 та 25 вересня, 5, 15 та 25 жовтня(чинник А). При кожному строкові сівби використовували два фрони живлення рослин: природний фон та прикореневе підживлення посівів пшениці озимої азотними добривами у нормі $\mathrm{N}_{33}$ наприкінці фази весняного кущіння(чинник

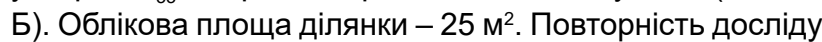
чотириразова. Технологія вирощування пшениці озимої за виключенням досліджуваних фракторів розроблена в інституті сільського господарства Степу НААН.

Ґрунти дослідної ділянки - чорноземи звичайні середньогумусні важкосуглинкові глибокі. Для цих ґрунтів характерний дуже глибокий гумусний профріль (80-100 см) зі значною глибиною гумусного горизонту (40-50 см) та добре виявленою зернистою структурою. До низу вона поступово переходить у зернисто-дрібно-грудочкувату. Вміст гумусу $-4,54 \%$. Вміст рухомих форм поживних речовин у ґрунті становить 14,5 мг гідролізованого азоту, 12,1 мг фоосфору та 15,7 мг калію на 100 г ґрунту. Сума ввібраних основ становить 39,4 мг на 100 г ґрунту, $\mathrm{pH}$ сольове $-5,6$.

Погодні умови у роки проведення досліджень за основними показниками загалом були характерними для зони північного Степу України. Водночас у кожному із років досліджень були прояви тих чи інших погодних явищ, які вирізняли роки досліджень між собою та від середньобагаторічних показників. Температурний режим повітря впродовж жовтня у всі роки досліджень був вищим порівняно із середньобагаторічними даними. Водночас у листопаді 2017 та 2019 років показники середньодобової температури повітря були вищими, ніж багаторічні показники, а тому відбулося подовження осінньої вегетації, тоді як у 2016 та 2018 роках - навпаки, нижчими. Таким чином, припинення осінньої вегетації рослин пшениці озимої відбувалося у різні строки. У всі роки досліджень умови зимового періоду виявилися сприятливими для доброї перезимівлі рослин пшениці озимої.

У 2017, 2019 та 2020 роках спостерігалося раннє відновлення весняної вегетації рослин, тоді як у 2018 році - пізнє. Натомість у всі роки досліджень температурний режим повітря впродовж весняно-літнього періоду вегетації рослин пшениці озимої був вищим за середньобагаторічні показники. У 2020 році спостерігалися пізні приморозки як на поверхні ґрунту, так і в повітрі. Це негативно вплинуло на формування врожаю пшениці озимої.

В усі роки досліджень кількість опадів впродовж весняно-літньої вегетації виявилася меншою за багаторічні показники. Критично посушливі умови 2017 року викликали різке зниження рівня врожайності посівів пшениці озимої навіть на фоні раннього відновлення весняної вегетації. 3 березня по червень включно загальна кількість опадів становила лише 61,5 мм проти 174 мм як багаторічного показника. У 2018 та 2020 роках кількість опадів за вказаний період становила відповідно 138,2 та 141,6 мм. Найбільш сприятливі умови щодо вологозабезпечення склалися у 2019 році. Впродовж весняно-літньої вегетації випало 166 мм опадів.

Результати досліджень. Отримані результати досліджень свідчать про значний вплив строків сівби та підживлення посівів пшениці озимої у ранньовесняний період на подальший ріст та розвиток рослин, а відповідно і формування врожаю. Серед досліджуваних факторів найбільший вплив на формування врожаю посівами пшениці озимої чинили строки сівби. Варіювання рівня врожайності під впливом строків сівби у різні роки досліджень становило від 0,64 до 2,37 т/га. Найбільш великий вплив строків сівби на рівень врожайності виявили у 2018 та 2019 роках досліджень. Так, в умовах 2018 року зміна строків сівби викликала варіювання рівня врожайності пшениці озимої від 4,29 т/га до 6,59 т/га, а у 2019 році - від 2,74 до 5,10 т/га. Менш помітною виявилася дія строків сівби на врожайність пшениці озимої у 2017 та 2020 роках. У ці роки зміна рівня врожайності внаслідок переміщення строків сівби становила відповідно 3,11 - 4,08 т/га та 4,38 - 4,11 т/га (табл. 1).

В умовах 2016/2017 вегетаційного року на фоні тривалої осінньої вегетації та раннього відновлення iï весною, 3 відносно коротким перехідним періодом середньодобових температур повітря від $0{ }^{\circ} \mathrm{C}$ до $+5{ }^{\circ} \mathrm{C}$ урожайність пшениці озимої із сівбою в період з 15 вересня по 5 жовтня була найбільш високою та істотно не різнилася між собою. Дані табл. 1 свідчать, що у зазначений період сівби врожайність становила від 3,99 до 4,08 т/га (HIP $05=0,09)$. Переміщення сівби на більш пізні терміни викликало істотне зменшення врожайності пшениці озимої до 3,11-3,35 т/га.

Погодні умови 2017/2018 року виявилися найбільш сприятливими для росту та розвитку рослин пшениці озимої. Достатня кількість опадів восени, особливо у жовтні (192\% від середньобагаторічних даних) у комплексі зі сприятливим температурним режимом та подовженою осінньою вегетацією забезпечило формування високих потенційних можливостей посівів пшениці 
Вплив строків сівби на врожайність пшениці озимої, т/га

\begin{tabular}{|c|c|c|c|c|c|c|}
\hline \multirow{2}{*}{ Рік } & \multicolumn{5}{|c|}{ Строк сівби } & \multirow{2}{*}{$\mathrm{HIP}_{05}$} \\
\hline & 15.IX & $25 . I X$ & $5 . X$ & $15 . X$ & $25 . X$ & \\
\hline 2017 p. & 4,05 & 4,08 & 3,99 & 3,35 & 3,11 & 0,09 \\
\hline 2018 p. & 6,48 & 6,59 & 6,46 & 5,30 & 4,29 & 0,12 \\
\hline 2019 p. & 4,93 & 5,10 & 4,41 & 2,79 & 2,74 & 0,06 \\
\hline 2020 p. & 4,11 & 4,19 & 4,78 & 4,57 & 4,38 & 0,11 \\
\hline Середнє & 4,89 & 4,99 & 4,91 & 4,00 & 3,63 & \\
\hline
\end{tabular}

Таблиця 2

Вплив прикореневого азотного підживлення посівів пшениці озимої у ранньовесняний період на їх врожайність, т/га

\begin{tabular}{|c|c|c|c|c|c|c|c|}
\hline Строк сівби & Підживлення & 2017 p. & 2018 p. & 2019 p. & 2020 p. & Середнє & $\begin{array}{c}\text { Середнє по } \\
\text { фактору В }\end{array}$ \\
\hline \multirow{2}{*}{ 15.IX } & без прикореневого підживлення & 3,71 & 6,2 & 4,44 & 3,81 & 4,54 & 4,13 \\
\hline & прикореневе підживлення $\mathrm{N}_{33}$ & 4,40 & 6,77 & 5,42 & 4,40 & 5,25 & 4,68 \\
\hline \multirow{2}{*}{ 25.IX } & без прикореневого підживлення & 3,74 & 6,35 & 4,59 & 3,92 & 4,65 & \\
\hline & прикореневе підживлення $\mathrm{N}_{33}$ & 4,42 & 6,83 & 5,62 & 4,46 & 5,33 & \\
\hline \multirow{2}{*}{ 5. $X$} & без прикореневого підживлення & 3,61 & 6,19 & 4,08 & 4,37 & 4,56 & \\
\hline & прикореневе підживлення $\mathrm{N}_{33}$ & 4,37 & 6,72 & 4,75 & 5,18 & 5,26 & \\
\hline \multirow{2}{*}{ 15. $X$} & без прикореневого підживлення & 3,01 & 5,10 & 2,53 & 4,33 & 3,74 & \\
\hline & прикореневе підживлення $\mathrm{N}_{33}$ & 3,69 & 5,50 & 3,05 & 4,82 & 4,27 & \\
\hline \multirow{2}{*}{ 25. $X$} & без прикореневого підживлення & 2,78 & 3,95 & 2,51 & 4,20 & 3,36 & \\
\hline & прикореневе підживлення $\mathrm{N}_{33}$ & 3,44 & 4,62 & 2,97 & 4,56 & 3,90 & \\
\hline $\mathrm{HIP}_{05}$ & & 0,08 & 0,10 & 0,05 & 0,09 & & \\
\hline
\end{tabular}

озимої на час припинення осінньої вегетації. Навіть на фоні пізнього відновлення весняної вегетації рослин (1 квітня) врожайність за всіх строків сівби виявилася найбільш високою за всі роки досліджень. Істотно більшою врожайність пшениці озимої сформувалася при сівбі 15 та 25 вересня - відповідно 6,48 та 6,59 т/га($\left.\mathrm{HIP}_{05}=0,12\right)$. У варіантах із більш пізньою сівбою вона істотно знижувалася, і найбільш низькою $(4,29$ т/га) вона була при сівбі 25 жовтня.

В останні 2019 та 2020 роки досліджень, незважаючи на різні погодні умови впродовж вегетації рослин, дія строків сівби на врожайність посівів пшениці озимої виявилася майже тотожною. В обидва роки досліджень сівба 15 вересня не забезпечувала формування найбільш високої врожайності. У 2019 році максимальна істотно вища врожайність порівняно з іншими строками сівби отримана у варіанті з сівбою 25 вересня, вона становила 5,1 т/га. Сівба у більш пізні строки сприяла істотному зниженню врожайності. При цьому найбільш значне зниження відзначалося у варіантах із сівбою 15 та 25 жовтня, урожайність відповідно становила 2,79 та 2,74 т/га.

У 2019/2020 вегетаційному році найбільш висока врожайність сформувалася при сівбі 5 жовтня, і вона становила 4,78 т/га. При сівбі 15 та 25 вересня зниження врожайності пшениці озимої відбулося внаслідок тривалої осінньої вегетації на фоні підвищеного температурного режиму та певного дефріциту вологи у грудні. При цьому відбулося не лише пошкодження рослин приховано-стебловими шкідниками, а й ураження їх хворобами уже в осінній період. Грудень місяць і загалом весь зимовий період виявився значно теплішим за середньобагаторічні показники. Вегетація рослин впродовж грудня та надраннє відновлення весняної вегетації в лютому сприяли процесу кущення рослин пшениці озимої та збільшення їх ваги. У кінцевому результаті це забезпечило підвищення врожайності посівами пшениці озимої із сівбою 15 та навіть 25 жовтня. Вона досягла рівня 4,57 та 4,38 т/га. Слід зазначити, що лише в цьому році, завдячуючи таким погодним умовам осіннього та ранньовесняного періодів, врожайність посівів пшениці озимої пізніх строків сівби була істотно більшою, ніж у варіантах із сівбою 15 та 25 вересня.

Формування високої врожайності посівами пшениці озимої неможливе без задоволення біологічних потреб іiї рослин в елементах мінерального живлення. Серед них найбільш важлива роль відводиться азоту. Уже впродовж тривалого періоду в усіх регіонах України прикореневе підживлення посівів пшениці озимої азотними добривами у ранньовесняний період $є$ загальноприйнятим агротехнічним прийомом. Його використання зумовлено не лише ґрунтово-кліматичними особливостями того чи іншого регіону, а й організаційно-економічним станом сільськогосподарських підприємств. Більшістю польових досліджень доведена незаперечна позитивна дія такого агротехнічного прийому. Але ефективність прикореневих підживлень у ранньовесняний період залежить від багатьох фракторів природного походження.

В усі роки досліджень за всіх строків сівби проведення прикореневого підживлення посівів пшениці озимої азотними добривами у нормі $\mathrm{N}_{33}$ наприкінці фрази кущіння сприяло істотному підвищенню їх урожайності (табл. 2). Разом із тим абсолютні та відносні приро- 
сти рівня врожайності внаслідок застосування азотних добрив залежали від погодних умов у тому чи іншому році досліджень. У 2017 році, який характеризувався раннім відновленням весняної вегетації та дефіцитом опадів упродовж усього весняного періоду, прибавка врожаю внаслідок застосування азотного підживлення становила від 0,66 до 0,76 т/га залежно від строків сівби. Це єдиний із років досліджень, в якому ефективність прикореневого підживлення майже не залежала від строків сівби. У чотирьох із п'яти досліджуваних нами строків сівби прибавка врожаю становила 0,66-0,69 т/га, і лише за сівби 5 жовтня вона істотно відрізнялася і становила 0,76 т/га.

У 2018 році, коли в осінній період погодні умови виявилися найбільш сприятливими для росту та розвитку рослин пшениці озимої, а відповідно, сформувалися високі потенційні можливості посівів, прикореневе підживлення весною підвищувало врожайність пшениці озимої на 0,4-0,67 т/га (HIP $05=0,10)$. За сівби починаючи з 15 вересня і закінчуючи 15 жовтня прибавка врожаю становила 0,4-0,57 т/га, або 7,6-9,2\% порівняно 3 варіантами без підживлення. За надпізнього строку сівби 25 жовтня ефективність використання азотних добрив виявилася найбільш високою. Врожайність досягла найвищого рівня за всі роки досліджень за цього строку сівби і становила 4,62 т/га, прибавка врожаю - 0,67 т/га, що на 17,0\% більше порівняно з контрольним варіантом.

Дія прикореневого підживлення азотними добривами в умовах 2020 року загалом була тотожною до попереднього року досліджень. Головною відміною виявилося те, що найбільша прибавка врожаю $(0,81$ т/га) була отримана за сівби 5 жовтня. Саме за цього строку сівби у 2020 році отримана найбільш висока врожайність. Зміщення строків сівби в обидва боки викликало не лише істотне зменшення рівня врожайності, а й зниження ефективності прикореневого підживлення. Так, у варіантах з сівбою 15 та 25 вересня прибавка врожаю становила відповідно 0,59 та 0,54 т/га, а при надпізніх строках сівби 15 та 25 жовтня - відповідно 0,49 та 0,36 т/га $\left(\mathrm{HIP}_{05}=0,09\right)$.

Більш глибокий аналіз отриманих результатів досліджень дає змогу стверджувати, що чим кращі умови росту та розвитку рослин пшениці озимої, тим нижчими $€$ абсолютні та відносні прирости рівня врожайності внаслідок проведення прикореневого підживлення посівів пшениці озимої (табл. 3).

Таблиця 3

Ефективність позакореневого підживлення пшениці озимої у ранньовесняний період

\begin{tabular}{|c|c|c|c|}
\hline \multirow{2}{*}{ Рік } & \multirow{2}{*}{$\begin{array}{c}\text { Урожайність, } \\
\text { т/га }\end{array}$} & \multicolumn{2}{|c|}{$\begin{array}{c}\text { Прибавка врожаю внаслідок } \\
\text { проведенн прикореневого } \\
\text { підживлення } \mathbf{N}_{33}\end{array}$} \\
\cline { 3 - 4 } & & т/га & $\%$ \\
\hline 2017 & 3,72 & 0,69 & 20,8 \\
\hline 2019 & 4,00 & 0,73 & 20,0 \\
\hline 2020 & 4,41 & 0,56 & 13,5 \\
\hline 2018 & 5,82 & 0,53 & 10,0 \\
\hline
\end{tabular}

Дані таблиці 3 відображують прямолінійний кореляційний взаємозв'язок між рівнем врожайності пшениці озимої та абсолютними і відносними показниками прибавки врожаю, зумовленими прикореневим підживленням у нормі $\mathrm{N}_{33}$. У 2017 році з найнижчим рівнем врожайності пшениці озимої (3,72 т/га) прибавка врожаю в результаті проведення прикореневого підживлення становила $20,8 \%$, тоді як у 2018 році 3 найбільш високою врожайністю (5,82 т/га) вона була меншою і становила лише 10,0\%.

Разом ыз цим ефективність використання азотних добрив для проведення прикореневого підживлення посівів пшениці озимої після сої в північному Степу України є досить високою у різні за погодними умовами роки (рис. 1).

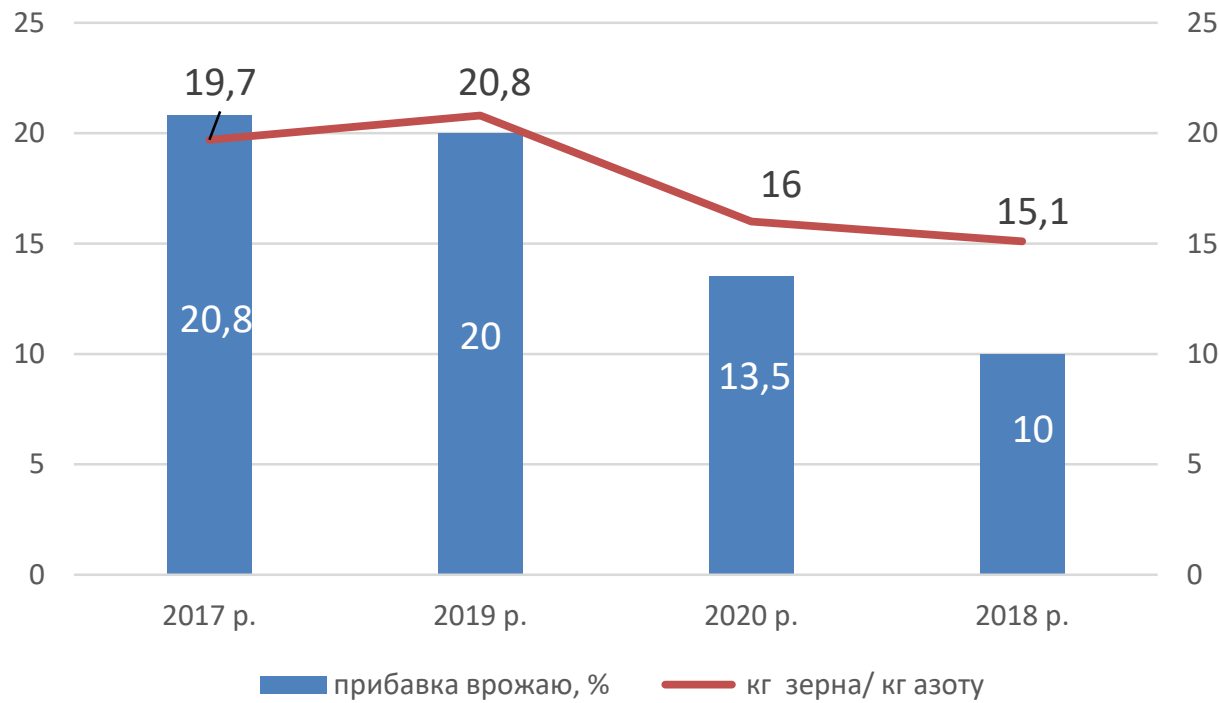

Рис. 1. Ефективність використання азоту для прикореневого підживлення посівів пшениці озимої 
Використання одного кілограму азоту для позакореневого підживлення посівів пшениці озимої забезпечує досить високі абсолютні прирости зерна пшениці озимої. За роки досліджень вони становили у межах 15,1-20,8 кг зерна/кг азоту. Натомість, коли у 2018 році погодні умови були найбільш сприятливими для росту та розвитку рослин пшениці озимої, прибавка врожаю під впливом прикореневого підживлення у відносних показниках виявилася найменшою і становила лише $10 \%$ порівняно з контрольним варіантом, то окупність азоту залишилася високою і становила 15,1 кг зерна/кг азоту. Зменшення окупності азоту зерном пшениці озимої у 2018 році порівняно з 2019 роком, коли вона була найбільш високою (20,8 кг зерна/кг азоту), становило лише $27,5 \%$. Отже, в північному Степу України прикореневе підживлення посівів пшениці озимої наприкінці фрази кущення азотними добривами $є$ високоефективним агротехнічним прийомом підвищення їх продуктивності у різні за погодними умовами роки.

Висновки. В умовах північного Степу України найбільш висока врожайність зерна пшениці озимої після сої на зерно формується при сівбі у період з 15 вересня по 5 жовтня. У середньому за роки досліджень вона становила 4,89-4,99 т/га. Більш пізня сівба викликає істотне зменшення рівня врожайності. Прикореневе підживлення азотними добривами наприкінці фрази кущіння забезпечує істотне зростання врожайності посівів пшениці озимої незалежно від строків їх сівби та погодних умов упродовж вегетації ії рослин. У середньому за роки досліджень прибавка врожаю внаслідок прикореневого підживлення становила 0,55 т/га.

Незалежно в умовах північного Степу України спостерігається висока окупність азоту зерном пшениці озимої, використаного для прикореневого підживлення їі посівів наприкінці фази кущіння рослин. Найбільш висока ефективність дії азоту спостерігається у роки з проявом тих чи інших несприятливих фракторів і становить 20,8 кг зерна/кг азоту. У роки, коли умови навколишнього середовища $є$ сприятливими для формування врожаю, окупність азоту зерном пшениці озимої зменшується, але залишається високою і становить 15,1 кг зерна / кг азоту, тобто зниження ефективності дії азоту у такі роки не перевищує $27,5 \%$.

\section{СПИСОК ВИКОРИСТАНОÏ ЛІТЕРАТУРИ}

1. Орлюк А.П., Гончарова К.В. Адаптивний і продуктивний потенціал пшениці: монографія. Херсон: Айлант, 2002. 274 c.

2. Вовкодав В., Гончар О., Захарчук О., Климович В. Нові сорти зернових можуть істотно поліпшити якість збіжжя та підвищити його врожайність. Зерно і хліб. 2005. № 1. С. 38-39.

3. Господаренко Г.М., Єщенко Н.Б. Урожайність пшениці озимої на чорноземі опідзоленому правобережного Лісостепу залежно від різних видів і норм добрив та їх окупність. Збірник наукових праць Уманського національного університету садівництва. 2013. Вип. 82. Ч. 1. С. 8-14.

4. Вожегова Р.А. Сергєєв Л.А. Оптимізація систем удобрення та захисту рослин для підвищення насіннєвої продуктивності пшениці озимої в умовах півдня України. Таврійський науковий вісник. 2018. Вип. 100. Т. 1. С. 25-30.

5. Лихочвор В.В. Мінеральні добрива та їх застосування. Львів: Українські технології, 2008. 109 с.

6. Romheld V., Rirkby E. Research on nitrogen and potassium in agriculture: needs and prospects. Plant and Soil. 2010. Vol. 335. P. 155-180.

7. Лісовий М.В. Підвищення ефективності мінеральних добрив. К: Урожай, 1991. 120 с.

8. Польовий В.М. Оптимізація систем удобрення у сучасному землеробстві. Рівне: Волинські обереги, 2007. 320 c.

9. Шеуджен А.Ч., Бондарева Т.Н., Кизинек С.В. Агрохимические основы применение удобрений. Майкон: Полиграфф ЮГ, 2013. 570 с.

10. Филипьев И.Д., Криштопа В.И., Криштопа П.А. Миграция нитратов в орошаемой темно-каштановой среднесуглинистой почве. Плодородие мелиорационных земель УССР и пути его повышения. Киев: ЮО ВАСХНИЛ. 1988. С. 90-93.

11. Мостіпан М.І. Реакція пшениці озимої на час припинення осінньої вегетації в північному Степу України. Вісник Полтавської державної аграрної академії. 2019. № 1(24). C. 116-126.

12. Конопльова Є.Л. Особливості росту та розвитку рослин пшениці озимої у період весняно-літньої вегетації в північному Степу України. Бюлетень Інституту сільського господарства степової зони НААН України. 2013. № 4. С. 116-119.

13. Мостіпан М.І., Гульванський І.М., Матвєєва В.О. Оптимізація умов азотного живлення посівів озимої пшениці у ранньовесняний період вегетації. Охорона грунтів. 2018. Вип. 7. С. 33-40.

14. Мостипан Н.И., Шепилова Т.П., Васильковская К.В. Оптимизация условий азотного питания посевов пшеницы озимой в северной Степи Украины. Приемы повышения плодородия почв и эфффективности удобрений. Материалы межд. научн.-практ. конф., посвященной памяти учених: Анны Ивановны Горбылевой, Юрия Павловича Сиротина и Вадима Ивановича Тюльпанова. (Горки, 18-20 декабря 2018 г). Часть 2. Горки, 2019. С. 56-58.

15. Mostipan M., Umrychin N,, Mytsenko V. The interrelation between the productivity of winter wheat and weather conditions in autumn and early spring periods in the Northern Steppe of Ukraine. Stinga Agricola. Agricultural Science. 2019. Vol. 52(1). P. 10-16.

16. Mostipan M.,. Vasylkovska K, Andriienko O., Kovalov M., Umrykhin N. Productivity of winter wheat in the northern Steppe of Ukraine depending on weather conditions in the early spring period. Agronomy Research. 2021. $19(\mathrm{X}), 562-573$.

17. Николаев Е.В., Изотов А.М. Пшеница в Крыму. Симферополь: Сонат, 2001. 285 с.

\section{REFERENCES:}

1. Orliuk A.P., Honcharova K.V.(2002). Adaptyvnyi i produktyvnyi potentsial pshenytsi:monohrafiia [Adaptive and productive potential of wheat]. Kherson:Ailant [in Ukrainian].

2. Vovkodav V., Honchar O., Zakharchuk O., \& Klymovych V. (2005). Novi sorty zernovykh mozhut istotno polipshyty yakist zbizhzhia ta pidvyshchyty yoho vrozhainist [New 
varieties of cereals can significantly improve the quality of grain and increase its yield]. Zerno $i$ khlib,.№1. 38-39 [ in Ukrainian].

3. Hospodarenko H.M., Yeshchenko N.B. (2013). Urozhainist pshenytsi ozymoi na chornozemi opidzolenomu pravoberezhnoho Lisostepu zalezhno vid riznykh vydiv i norm dobryv ta yikh okupnist [Yields of winter wheat on chernozem podzolic right-bank Forest-Steppe depending on different types and rates of fertilizers and their payback]. Zbirnyk naukovykh prats Umanskoho natsionalnoho universytetu sadivnytstv, 82 (1). 8-14 [in Ukrainian].

4. Vozhehova R.A., Serhieiev L.A.(2018). Optymizatsiia system udobrennia ta zakhystu roslyn dlia pidvyshchennia nasinnievoi produktyvnosti pshenytsi ozymoi v umovakh pivdnia Ukrainy [Optimization of fertilizer and plant protection systems to increase the seed productivity of winter wheat in the south of Ukraine]. Tavriiskyi naukovyi visnyk. Vyp. 100. T. 1. 25-30 [in Ukrainian].

5. Lykhochvor V.V.(2008). Mineralni dobryva ta yikh zastosuvannia [Mineral fertilizers and their application]. Lviv:Ukrainski tekhnolohii [in Ukrainian].

6. Romheld V., Rirkby E. (2008). Research on nitrogen and potassium in agriculture: needs and prospects Plant and Soil. Vol. 335. 155-180.

7. Lisovyi M.V. (1991). Pidvyshchennia efektyvnosti mineralnykh dobryv [Improving the efficiency of mineral fertilizers]. Kyiv: Urozhai [in Ukrainian].

8. Polovyi V.M. (2007). Optymizatsiia system udobrennia u suchasnomu zemlerobstvi[Optimization of fertilizer systems in modern agriculture]. Rivne: Volynski oberehy [in Ukrainian].

9. Sheudzhen A.Ch., Bondareva T.N., \& Kyzynek S.V. (2013). Agrohimicheskie osnovyi primenenie udobreniy. [Agrochemical basis for the application of fertilizers]. Maikon: Polyhraf YuH [in Russian].

10. Fylypev Y.D., Kryshtopa V.Y., \& Kryshtopa P.A. (1988). Myhratsyia nytratov $v$ oroshaemoi temno-kashtanovoi srednesuhlynystoi pochve [Migration of nitrates in irrigated dark chestnut medium loamy soil]. Plodorodye melyoratsyonnykh zemel USSR y puty eho povyshenyia. 90-93 [in Russian].

11. Mostipan M.I.(2019). Reaktsiia pshenytsi ozymoi na chas prypynennia osinnoi vehetatsii $v$ pivnichnomu Stepu Ukrainy [Reaction of winter wheat at the time of cessation of autumn vegetation in the northern steppe of Ukraine]. Visnyk Poltavskoi derzhavnoi ahrarnoi akademii, 1(24). 116-126 [in Ukrainian].

12. Konoplova Ye. L. (2013). Osoblyvosti rostu ta rozvytku roslyn pshenytsi ozymoi u period vesniano-litnoi vehetatsii $v$ pivnichnomu Stepu Ukrainy [Features of growth and development of winter wheat plants during the spring-summer vegetation in the northern steppe of Ukraine]. Biuleten Instytutu silskoho hospodarstva stepovoi zony NAAN Ukrainy. 4. 116-119 [ in Ukrainian].

13. Mostipan M.I., Hulvanskyi I.M., \& Matvieieva V.O.(2018). Optymizatsiia umov azotnoho zhyvlennia posiviv ozymoi pshenytsi u rannovesnianyi period vehetatsii [Optimization of nitrogen nutrition conditions for winter wheat crops in the early spring growing season]. Okhorona hruntiv, 7. 33 - 40 [ in Ukrainian].

14. Mostypan N.Y., Shepylova T.P., Vasylkovskaia K.V. (2019). Optimizatsiya usloviy azotnogo pitaniya posevov pshenitsyi ozimoy $v$ severnoy Stepi Ukrainyi.
[Optimization of nitrogen nutrition conditions for winter wheat crops in the northern Steppe of Ukraine]. Priemyi povyisheniya plodorodiya pochv i effektivnosti udobreniy. Materialyi mezhd. nauchn.-prakt. konf., posvyaschennoy pamyati uchenih: Annyi Ivanovnyi Gorbyilevoy, Yuriya Pavlovicha Sirotina i Vadima Ivanovicha Tyulpanova. (pp. 56-58) Horky [in Russian]. 15. Mostipan M., Umrychin N., \& Mytsenko V. (2019). The interrelation between the productivity of winter wheat and weather conditions in autumn and early spring periods in the Northern Steppe of UkraineStinga Agricola. Agricultural Science. Vol.52(1). 10-16.

16. Mostipan M.,. Vasylkovska K, Andriienko O., Kovalov M., \& Umrykhin N.(2021). Productivity of winter wheat in the northern Steppe of Ukraine depending on weather conditions in the early spring period Agronomy Research. 19(X), 562-573 URL: https://doi.org/10.15159/ AR.21.090.

17. Nykolaev E.V., \& Yzotov A.M. (2001). Pshenitsa $v$ Kryimu. [Wheat in Crime]. Myferopol: Sonat [in Russian].

Мостіпан М.І., Умрихін Н.Л. Ефективність прикореневого підживлення посівів пшениці озимої в Північному Степу України

Головна мета досліджень полягала у визначенні ефективності проведення прикореневого підживлення посівів пшениці озимої після сої на зерно за різних строків сівби.

Сівбу пшениці озимої сорту Антонівка після сої на зерно проводили у такі строки: 15 та 25 вересня, 5, 15 та 25 жовтня. Прикореневе підживлення різновікових посівів пшениці озимої проводили наприкінці фрази кущіння рослин азотними добривами у нормі $\mathrm{N}_{33}$. Основні обліки та спостереження проведені за загальноприйнятими методиками.

В умовах північного Степу України найбільш висока врожайність зерна пшениці озимої після сої на зерно формується при сівбі у період з 15 вересня по 5 жовтня. У середньому за роки за роки досліджень вона становила 4,89-4,99 т/га. Більш пізня сівба викликає істотне зменшення рівня врожайності. У середньому за роки досліджень перенесення сівби з 5 на 15 жовтня зменшувало врожайність пшениці на 0,91 т/га з коливанням у різні роки від 0,21 до 1,62 т/га (HIP $05=0,06-0,12)$.

Прикореневе підживлення азотними добривами забезпечує істотне зростання врожайності посівів пшениці озимої незалежно від строків їх сівби та погодних умов упродовж вегетації її рослин. У середньому за роки досліджень прибавка врожаю внаслідок прикореневого підживлення становила 0,55 т/га.

Незалежно від погодних умов в умовах північного Степу України спостерігається висока ефективність азоту, використаного для прикореневого підживлення посівів пшениці озимої у ранньовесняний період. Найбільша віддача азоту спостерігається у роки із проявом дії тих чи інших несприятливих факторів і становить 20,8 кг зерна/кг азоту. У роки, коли умови навколишнього середовища є сприятливими для формування врожаю, окупність азоту зерном пшениці озимої зменшується, але залишається високою і становить 15,1 кг зерна / кг азоту, тобто зниження ефективності дії азоту у такі роки не перевищує $27,5 \%$.

Ключові слова: врожайність, азотні добрива, строки сівби, погодні умови, окупність азоту. 
Mostipan M.I., Umrykhin N.L. Efficiency of Root Fertilization of Winter Wheat Crops in Northern Steppe of Ukraine

The main objective of the study was to determine the effectiveness of root fertilization of winter wheat crops after soybeans for grain at different sowing dates.

Sowing of Antonivka winter wheat after soybeans for grain was carried out in the following terms: September $15^{\text {th }}$ and $25^{\text {th }}$, October $5^{\text {th }}, 15^{\text {th }}$ and $25^{\text {th }}$. Root fertilization of winter wheat crops of different ages was carried out at the end of the tillering phase of plants with nitrogen fertilizers in the norm of $\mathrm{N}_{33}$. The main records and observations were carried out according to generally accepted methods.

In the conditions of northern Steppe of Ukraine, the highest grain productivity of winter wheat after soybeans for grain is formed during sowing period from September $15^{\text {th }}$ to October $5^{\text {th }}$. On the average, during the research it has made 4,89-4,99 t/hectare. Later sowing causes a significant decrease in productivity. On average, over the years of research, the transfer of sowing period from October $5^{\text {th }}$ to October $15^{\text {th }}$ reduced productivity of wheat by $0,91 \mathrm{t} /$ ha with fluctuations in different years from 0,21 to $1,62 \mathrm{t} / \mathrm{ha}\left(\mathrm{HIP}_{05}=0,06-0,12\right)$.

Root fertilization with nitrogen fertilizers provides a significant increase in the productivity of winter wheat crops, regardless of the sowing period and weather conditions during the growing season of plants. On average over the years of research, the increase in productivity due to root fertilization was $0,55 \mathrm{t} / \mathrm{ha}$.

Irrespective of weather in the conditions of northern Steppe of Ukraine, high efficiency of nitrogen used for root fertilization of winter wheat crops in the early spring period is observed. The greatest productivity of nitrogen is observed in the years with the manifestation of certain adverse factors and is $20,8 \mathrm{~kg}$ of grain/ $\mathrm{kg}$ of nitrogen. In the years when environmental conditions are favorable for the formation of the crop, the productivity of nitrogen by winter wheat decreases but remains high and is $15,1 \mathrm{~kg}$ of grain $/ \mathrm{kg}$ of nitrogen, that is reducing the efficiency of nitrogen in such years does not exceed $27,5 \%$.

Key words: productivity, nitrogen fertilizers, sowing dates, weather conditions, nitrogen productivity. 